\title{
A produção de uma estrutura dual na educação nacional e a relação cultural do brasileiro com o trabalho
}

Josí Aparecida de Freitas ${ }^{1}$

\section{RESUMO}

Este texto problematiza as relações culturais que se produziram historicamente entre o brasileiro e o trabalho, de tal forma que, no Brasil, produziu-se uma estrutura dual para a educação nacional em que o ensino profissionalizante é direcionado às camadas mais pobres da população, enquanto o ensino regular é reservado às classes mais abastadas. Busca-se inspiração na genealogia foucaultiana, enquanto recurso teórico-metodológico, entendendo-a, segundo Michel Foucault, como um acoplamento dos conhecimentos eruditos e das memórias locais, que permite a constituição de um saber histórico das lutas e a utilização desse saber nas táticas atuais. O exercício genealógico se dará pela análise da obra clássica Raízes do Brasil, de Sérgio Buarque de Holanda, de 1936 - a partir da qual se pretende problematizar a tradição escravista que marcou profundamente o significado e a valorização do trabalho no país, sobretudo manual, constituindo-se como uma ética do desvalor do trabalho. Com base nessa relação discriminatória discute-se a produção de uma educação, no Brasil, que separou o ensino profissional - assistencialista e utilitarista - do ensino regular - propedêutico - e se interroga esta produtividade no presente.

Palavras-chave: Educação profissional. Dualismo. Trabalho.

\section{The production of a dual structure in the national education and the cultural relationship of brazilians with work}

\section{ABSTRACT}

This text problematizes the cultural relations that have occurred historically between the Brazilian and the work, in such a way that, in Brazil, a dual structure for the national education was produced, in which the vocational

1 Mestra em Educação pela Universidade de Santa Cruz do Sul. Doutoranda em Educação pela Universidade de Santa Cruz do Sul. Professora e Supervisora Pedagógica no Instituto Federal Sul-Rio-Grandense, Campus Venâncio Aires. E-mail japarecidafreitas@gmail.com 
education is directed to the poorest section of the population, while regular education is reserved for the wealthier classes. We seek inspiration in Foucault's genealogy as a theoretical-methodologica Iresource, according to Michel Foucault, as a coupling of scholarly knowledge and local memories, which allows the constitution of a historical knowledge of the struggles and the use of this knowledge in tactics current. The genealogical exercise will be based on the analysis of Sérgio Buarque de Holanda'sclassic Roots of Brazil, from 1936 - from which it is tried to problematize the slave tradition that deeply marked the meaning and appreciation of work in the country, especially manual, constituting as anethic of the devaluation of work. On the basis of this discriminatory relationship, we discuss the production of an education in Brazil that separated the professional education - assistentialist and utilitarian - from regular education propaedeutic - and questions this productivity in the present.

Keywords: Professional education. Dualism.Work.

\section{La producción de una estructura dual en el la educación nacional y la relación cultural del brasileño con el trabajo}

\section{RESUMEN}

Este texto problematiza las relaciones culturales que se produjeron históricamente entre el brasileño y el trabajo, de tal forma que, en Brasil, se produjo una estructura dual para la educación nacional en que la enseñanza profesional es direccionada a los más pobres de la población, mientras la enseñanza regular es reservada a la élite. Se busca inspiración en la genealogía foucaultiana como aporte teóricometodológico, entendiéndola, según Michel Foucault, como una unión de los conocimientos eruditos y de las memorias locales, que permiten la constitución de un saber histórico de las luchas y la utilización de dicho saber en las tácticas actuales. El ejercicio genealógico se dará a través del análisis de la obra clásica Raízes do Brasil, de Sérgio Buarque de Holanda, de 1936 - a partir de la cual se pretende problematizar la tradición esclavista que marcó profundamente el significado y la valorización del trabajo en el país, sobre todo, manual, constituyéndose como una ética del desvalor del trabajo. Con base en dicha relación discriminatoria se discute la producción de una educación, en Brasil, que separó la enseñanza profesional - asistencial y utilitarista - de la enseñanza regular - propedéutica - y se interroga esta productividad en el presente.

Palabras-clave: Educación professional.Dualismo.Trabajo 


\section{Introdução}

A formação para o trabalho no Brasil começou a ser feita desde os tempos mais remotos da colonização, tendo como os primeiros aprendizes de ofícios os índios e os escravos, de forma que "habituou-se o povo de nossa terra a ver aquela forma de ensino como destinada somente a elementos das mais baixas categorias sociais" (FONSECA, 1961, p. 68).

A escravidão no Brasil pode ser entendida, desta forma, como a desencadeadora de um caráter dualista que acompanha a educação profissional em sua trajetória histórica no país. $\mathrm{O}$ dualismo das políticas educacionais brasileiras, no âmbito da educação profissional, é o que Santos (2015) assinala como o privilégio que a sociedade brasileira direcionou, ao longo das décadas, ao ensino secundário, hoje chamado de Ensino Médio regular ou formação geral, em detrimento do Ensino Técnico / Educação Profissional. Tal dualidade reside na educação profissional ter tido um caráter assistencialista ao longo de sua história, reservada, por muito tempo, como explica Santos (2015), aos pobres ou "desvalidos da fortuna", aos operários das fábricas a quem se precisava ensinar os "ofícios manuais". O ensino secundário seria destinado aos futuros dirigentes do país, filhos da elite, aqueles a quem o ensino superior aguardava.

Este texto pretende buscar historicamente as condições de possibilidade para a produção desse dualismo. Para tanto, inspiro-me na genealogia que Michel Foucault (2016) traz de Nietzsche e que não parte em busca de uma "origem" como essência exata de algo, identidade ainda preservada ou começo histórico das coisas. Antes, Foucault (2016) articula genealogicamente a emergência - um ponto de surgimento de um acontecimento histórico, não como uma decisão, um tratado, uma batalha, mas uma relação de forças que se inverte, um poder confiscado, uma dominação que se enfraquece e outra que faz sua entrada - e proveniência - uma "perigosa herança" (FOUCAULT, 2016, p.63), que não é uma aquisição, um bem que se acumula e se solidifica, é, antes disso, um conjunto de falhas, de fissuras que ameaçam o corpo herdeiro. $\mathrm{O}$ corpo, enquanto superfície de inscrição de acontecimentos, está articulado com a história.

Nesse sentido, questiono: as relações histórico-culturais que se construíram no Brasil sobre o valor do trabalho podem ter algo a dizer 
sobre a produção da dualidade que se opera na educação profissional do país? O exercício genealógico, neste texto, para desenvolver esse questionamento, se dará pela análise de uma obra clássica que buscou interpretações para o Brasil - Raízes do Brasil, de Sérgio Buarque de Holanda, de 1936 - a partir da qual se pretende problematizar a tradição escravista que marcou profundamente o significado e a valorização do trabalho no país, sobretudo manual, constituindo-se como uma ética do desvalor do trabalho. Tal incursão genealógica contribui para a problematização das práticas discursivas ${ }^{2}$ da educação profissional contemporânea, tencionando-as quanto à produtividade desse dualismo no presente.

Como organização deste artigo, na primeira seção, serão abordadas as questões relacionadas à análise do clássico acima citado, com ênfase na gênese da relação cultural do brasileiro com o trabalho. Em uma segunda seção, o ensino de profissões no período colonial, imperial e no início da República, no Brasil, serão abordados em seu caráter assistencialista e utilitarista, legitimando a discriminação dos escravos na aprendizagem da manufatura. Em uma terceira e última seção, a educação profissional contemporânea é problematizada quanto à continuidade ou ruptura com o discurso dualista que acompanha a história dessa modalidade de ensino.

\section{A construção de uma desvalorização do trabalho no Brasil}

Raízes do Brasil, de Sérgio Buarque de Holanda (1995), publicada em 1936 em sua primeira edição, é uma obra que se propõe a buscar uma maneira de entender os descompassos que iriam formar nossa sociedade. Schwarcz e Starling (2015, p. 382) argumentam que o livro "traz a crítica aguda das soluções autoritárias adotadas sistematicamente no decorrer da história do país, alude os princípios formadores da sociedade brasileira, testa as possibilidades e expõe as tensões do processo de modernização do país".

Antonio Candido (1995), em prefácio ao livro, em 1967, observa que Raízes do Brasil é construído sobre uma metodologia de contrários,

2 Entendo como práticas discursivas "um conjunto de discursos em movimento, segundo um corpo de regras que, sendo socialmente autorizadas, anônimas e anteriores a qualquer conceituação explícita sobre si mesmas, comandam, em nós, maneiras de perceber, julgar, pensar e agir". (VEIGA-NETO, 2011, p. 95). 
em que o pensamento do autor explora conceitos polares sem a opção prática ou teórica por um deles, mas pelo enfoque simultâneo dos dois: "um suscita o outro, ambos se interpenetram e o resultado possui uma grande força de esclarecimento" (CANDIDO, 1995, p. 13). Assim, Sérgio Buarque de Holanda analisa, conforme Candido (1995), os fundamentos do nosso sentido histórico, mostrando a sua manifestação nos aspectos mais diversos: trabalho e aventura; método e capricho; rural e urbano; burocracia e caudilhismo; norma impessoal e impulso afetivo.

Candido (1995) explica que a ideia de cordialidade brasileira, que Holanda (1995) traz em Raízes do Brasil, introduz o "homem cordial" como o brasileiro que recebeu o peso das "relações de simpatia", por isso, não considera agradáveis as relações impessoais, características do Estado, procurando reduzi-las ao padrão pessoal e afetivo.

A tipologia básica do livro, segundo Candido (1995), se encontra no segundo capítulo - Trabalho \& Aventura - que distingue o trabalhador e o aventureiro. Este capítulo interessa aqui sobremaneira, juntamente com o primeiro - Fronteiras da Europa - não em detrimento dos demais, mas na medida em que aquele contribui para a compreensão específica da relação histórico-cultural do brasileiro com o trabalho enquanto delineia duas éticas importantes nesse sentido - a ética do trabalho e a ética da aventura - e este, por trazer as origens históricas, em relação ao colonizador europeu, necessárias ao entendimento das duas éticas.

Conforme Holanda (1995, p. 43), os portugueses, pioneiros da conquista dos trópicos, não promoveram essa exploração de forma metódica e racional, mas antes "com desleixo e certo abandono". Foram, desta maneira, o tipo denominado aventureiro.

Seu ideal será colher o fruto sem plantar a árvore. Esse tipo humano ignora as fronteiras. No mundo tudo se apresenta a ele em generosa amplitude e, onde quer que se erija um obstáculo a seus propósitos ambiciosos, sabe transformar esse obstáculo em trampolim. Vive dos espaços ilimitados, dos projetos vastos, dos horizontes distantes. (HOLANDA, 1995, p. 44).

O trabalhador, ao contrário, tem um objetivo final, a mira de todo esforço, o ponto de chegada. Enxerga primeiro a dificuldade a vencer, não o triunfo a alcançar. É persistente e mede todas as possibilidades de desperdício. Holanda (1995) - a partir dos conceitos de trabalhador 
e de aventureiro, ainda que não existentes em uma oposição absoluta, mas na condição de ordenadores dos conjuntos sociais dos homens no mundo das ideias - apresenta as éticas do trabalho e da aventura:

Existe uma ética do trabalho, como existe uma ética
da aventura. Assim, o indivíduo do tipo trabalhador
só atribuirá valor moral positivo às ações que sente
ânimo de praticar e, inversamente, terá por imorais
e detestáveis as qualidades próprias do aventureiro
- audácia, imprevidência, irresponsabilidade, insta-
bilidade, vagabundagem, - tudo, enfim, quanto se
relacione com a concepção espaçosa do mundo, ca-
racterística desse tipo. Por outro lado, as energias e
esforços que se dirigem a uma recompensa imediata
são enaltecidos pelos aventureiros; as energias que
visam à estabilidade, à paz, à segurança pessoal e aos
esforços sem perspectiva de rápido proveito material
passam, ao contrário, por viciosos e desprezíveis para
eles. Nada lhes parece mais estúpido e mesquinho do
que o ideal do trabalhador (HOLANDA, 1995, p. 44 ,
grifo).

Na época da conquista e colonização dos novos mundos pelos europeus, explica Holanda (1995), o trabalhador teve papel muito limitado. Logo, não é surpresa que no Brasil, o tipo trabalhador não tenha sido predominante como colonizador que aqui se estabeleceu, uma vez que, o século XVI, em que foi iniciada a colonização brasileira pelos portugueses, era época de "gestos e façanhas audaciosos, galardoando bem os homens de grandes voos" (HOLANDA, 1995, p. 45).

O fato de o Brasil ter sido colônia de uma nação ibérica é condição fundamental, segundo Holanda (1995, p. 31), para a constituição das formas como convivemos. "Todo o fruto de nosso trabalho ou de nossa preguiça parece participar de um sistema de evolução próprio de outro clima e de outra paisagem".

Para Holanda (1995), faltava ao português uma moral do trabaIho, própria das terras protestantes. Povo católico, os portugueses acreditavam que a ação sobre as coisas, sobre o universo material, implicaria em uma submissão ao mundo exterior, a uma lei que não é de Deus e que nada acrescentaria à sua glória ou à dignidade humana. $\mathrm{O}$ trabalho manual e mecânico visaria a uma perfeição de uma obra distinta do homem, prejudicando-o. 
É compreensível, assim, que jamais se tenha naturalizado entre gente hispânica a moderna religião do trabalho e o apreço à atividade utilitária. Uma digna ociosidade sempre pareceu mais excelente, e até mais nobilitante, a um bom português, ou a um espanhol, do que a luta insana pelo pão de cada dia. $\mathrm{O}$ que ambos admiram como ideal é uma vida de grande senhor, exclusiva de qualquer esforço, de qualquer preocupação. E assim, enquanto povos protestantes preconizam e exaltam o esforço manual, as nações ibéricas colocam-se ainda largamente no ponto de vista da Antiguidade clássica. O que entre elas predomina é a concepção antiga de que o ócio importa mais que o negócio e de que a atividade produtora é, em si, menos valiosa que a contemplação e o amor (HOLANDA, 1995, p. 38).

Candido (1995) explica que, em seu processo de análise, Holanda (1995) aproveita os estudos de Max Weber sobre a ética do trabalho como vantagem dos protestantes na luta econômica pela existência. De fato, segundo Weber (2004), as cidades mais ricas do Leste da Alemanha, como em quase toda parte em que o capitalismo estava em desenvolvimento, na Europa, no século XVI, já haviam se convertido ao protestantismo. A razão desse comportamento deve ser procurada, afirma Weber (2004), na peculiaridade intrínseca e duradoura de cada confissão religiosa, seja no catolicismo, seja no protestantismo.

Com a Reforma, explica Weber (2004), valoriza-se a ideia singular da profissão como dever de uma obrigação que o indivíduo deve sentir com respeito ao conteúdo de sua atividade profissional, seja qual for a "vocação profissional". Weber (2004, p. 73) observa que, no protestantismo, o cumprimento dos deveres mundanos é "a única via de agradar a Deus em todas as situações, que esta e somente esta é a vontade de Deus, e por isso toda profissão lícita simplesmente vale muito e vale igual perante Deus". Este teria sido, conforme Weber (2004) o feito propriamente dito da Reforma: ter inflado fortemente, em contraste com a concepção católica, a ênfase moral e o prêmio religioso para o trabalho mundano no quadro das profissões.

Da mesma forma, a reduzida capacidade de organização social dos portugueses também teria vindo em consequência da falta de uma disposição para o trabalho, estimulada pela crença católica, defende Holanda (1995). Ao contrário disso, os povos ibéricos estimulavam-se 
às ações aventurosas, à caça de bens materiais em outros continentes (África, Ásia, Américas), à ânsia por prosperidade sem custo, de posições, títulos e riquezas fáceis. "Ainda nos associa à península Ibérica, a Portugal, especialmente, uma tradição longa e viva, bastante viva para nutrir, até hoje, uma alma comum, a despeito de tudo quanto nos separa" (HOLANDA, 1995, p. 40).

O gosto dos portugueses pela aventura, afirma Holanda (1995), teve influência decisiva na vida nacional brasileira, uma vez que favoreceu a mobilidade social, estimulando, assim, o enfrentamento das asperezas ou resistências da natureza: as etnias que aqui se chocaram com os costumes e padrões que trouxeram da Europa, além da adaptação à terra, ao clima, à alimentação. Nesse sentido, o recurso mais fácil para o modelo de exploração agrária foi a latifundiária e monocultora devido à abundância de terras férteis ainda não cultivadas na colônia. A introdução de escravos africanos, depois que as tentativas de emprego da força indígena foram frustradas, resolveu o problema que ainda se apresentava: o do trabalho nas lavouras de cana-de-açúcar. "O que o português vinha buscar era, sem dúvida, a riqueza, mas riqueza que custa ousadia, não riqueza que custa trabalho" (HOLANDA, 1995, p. 49).

A escravidão e a monocultura latifundiária, explica Holanda (1995), tiveram como uma de suas consequências a ausência de esforços de cooperação nas demais atividades produtoras. A organização dos ofícios segundo os moldes europeus foi comprometida, aqui, pela preponderância do trabalho escravo, da indústria caseira que entravava o comércio por garantir produtos aos ricos e pela escassez de artífices livres na maior parte das vilas e cidades. Do trabalho considerado vil, que poderia calejar as mãos e, por isso, aproximar-se do trabalho escravo, o manufatureiro ou artífice fugia assim que pudesse: conseguia um "negro de ganho" ou "moço de ganho" que trabalhasse em seu benefício, exclusivamente, podendo assim tirar proveito dos trabalhos mais humildes sem esforço. “Embora a lei não tivesse cogitado em estabelecer qualquer hierarquia entre as diferentes espécies de trabalho manual, não se pode negar que existiam discriminações consagradas pelos costumes" (HOLANDA, 1995, p. 58).

Certa intolerância prevaleceu constantemente com relação aos ofícios de mais baixa reputação social muito em consequência da ética aventureira dos colonizadores portugueses, em virtude da qual, nos ofícios urbanos reinavam o mesmo amor ao ganho fácil e a infixidez que 
caracterizaram os trabalhos rurais. Além disso, Holanda (1995) destaca a influência dos negros como escravos, não apenas como negros, relaxando, suavizando, açucarando a vida colonial.

Sinuosa até na violência, negadora de virtudes sociais, contemporizadora e narcotizante de qualquer energia realmente produtiva, a 'moral das senzalas' veio imperar na administração, na economia e nas crenças religiosas dos homens do tempo. (HOLANDA, 1995, p. 62).

O personalismo brasileiro teve suas origens, conforme Holanda (1995), nessas relações em que há uma acentuação enérgica do afetivo, do irracional, do passional e uma estagnação das qualidades ordenadoras, disciplinadoras, racionalizadoras.

\section{O ensino de profissões do período colonial ao início da Repúblicano Brasil}

Luiz Antonio Cunha (2000), em estudo sobre o ensino industrial-manufatureiro no Brasil, complementa, de certa forma, as considerações de Holanda (1995) sobre as relações escravistas de produção na época colonial. Tais relações, afirma Cunha (2000), afastaram a força de trabalho livre do artesanato e da manufatura. $\mathrm{O}$ emprego de escravos como carpinteiros, ferreiros, pedreiros, tecelões etc., afugentava os trabalhadores livres dessas atividades, empenhados todos em se diferenciar do escravo, o que era da maior importância diante de senhores/ empregadores, que viam todos os trabalhadores como coisa sua. Por isso, dentre outras razões, as Corporações de Ofícios $^{3}$ (irmandades) não tiveram, no Brasil Colônia, o desenvolvimento de outros países. Homens livres se afastavam do trabalho manual para não deixar dúvidas quanto a sua própria condição. "Aí está a base do preconceito contra o trabalho

3 As Corporações de Ofícios eram agrupamentos profissionais que existiam, primeiramente, na Roma antiga, sob a forma de "colégios" em que se amalgamavam todos os artífices de uma mesma profissão, quer fossem livres, quer escravos. Na era medieval, as Corporações de Ofícios, na Europa, preocupavam-se coma transmissão de conhecimentos profissionais hierarquicamente organizados: mestres, oficiais e aprendizes. No Brasil, a aprendizagem de ofícios processava-se como em Portugal, também com a mesma organização hierárquica. Cada ofício estava regulamentado por um Regimento minucioso, detalhado, em que vinham expressas as condições de seu exercício, a matéria em que deveriam ser examinados os aprendizes, as sanções de caráter monetário e penal, assim como as eleições de seus dirigentes. A Constituição de 1824 declarou extintas as Corporações de Ofícios no Brasil (FONSECA, 1961). 
manual, inclusive e principalmente daqueles que estavam socialmente mais próximos dos escravos: mestiços e brancos pobres" (CUNHA, 2000, p. 90).

Assim, se havia a destinação do trabalho pesado e sujo (manual, evidentemente) ao escravo, havia, ao mesmo tempo, atividades manuais que os brancos livres queriam que ficassem preservadas para si. Nesses casos, as Corporações de Ofício faziam normas rigorosas, até mesmo com apoio das Câmaras Municipais, impedindo ou, pelo menos, desincentivando o emprego de escravo sem certos ofícios.

O Brasil, no século XVIII, conforme Santos (2015), estava fundado em um sistema convencionado como pacto colonial, ou seja, o exclusivo comércio com a metrópole Portugal. Por imposição dos portugueses, o modelo econômico era o agroexportador, com resistência, por parte do colonizador, em implantar indústrias na colônia. Desta forma, de 1706 a 1766, informa Santos (2015), muitos ramos de atividades foram fechados, como tipografias, oficinas e fundições de ourives. Por fim, em 1785, o Alvará de 05 de janeiro obrigava o fechamento de todas as fábricas, exceto as que tecessem roupas para o vestuário dos negros escravos. A aprendizagem de profissões, nessa época, ficou cerceada em seu desenvolvimento, uma vez que não havia onde empregar as atividades industriais ou manufatureiras.

A vinda de D. João VI para o Brasil, em 1808, retomou o processo de desenvolvimento industrial na colônia. $\mathrm{O}$ resultado do fechamento de indústrias e da ação discriminatória que recusava a determinados grupos sociais o desempenho de alguns ofícios foi a escassez de mão de obra em certas ocupações. Fonseca (1961) afirma que, com o Alvará de $1^{\circ}$ de abril de 1808, D. João VI não somente revogou o Alvará de 05 de janeiro de 1785 permitindo, assim, o estabelecimento de fábricas e manufaturas no Brasil, como também criou condições para que o ensino dos ofícios progredisse.

Ocorre que, dada a escassez de mão de obra, a aprendizagem compulsória dos miseráveis foi a opção dos governantes para empreendimentos manufatureiros de grande porte, como os arsenais de marinha, por exemplo. Como exigiam um contingente de trabalhadores não disponíveis, o Estado coagia homens livres a se transformarem em artífices. Não fazia isso, decerto, com quaisquer homens livres, mas com aqueles que social e politicamente não estavam em condições de opor 
resistência. Procedimentos semelhantes eram adotados para com os menores destinados à aprendizagem de ofícios: os órfãos, os abandonados, os desvalidos, que eram encaminhados pelos juízes e pelas Santas Casas de Misericórdia aos arsenais militares e de marinha, onde eram internados e postos a trabalhar como artífices até que, depois de um certo número de anos, escolhessem livremente onde, como e para quem trabalhar (CUNHA, 2000; SANTOS, 2015).

Com a Independência, em 1822, mesmo com a ampliação das forças produtivas, Santos $(2015$, p. 208) ressalta que "nenhum progresso para elevar o seu status [da educação profissional] se efetivou". Permaneceu no Império a mentalidade conservadora que havia sido construída ao longo de três séculos de duração do período colonial: "destinar tal ramo de ensino aos humildes, pobres e desvalidos, continuando, portanto, o processo discriminatório em relação às ocupações antes atribuídas somente a escravos".

Em 1826, o Projeto de Lei sobre a Instrução Pública no Império do Brasil objetivava estruturar o ensino no país, dividindo os estabelecimentos educacionais em quatro níveis: Pedagogias (destinados ao primeiro grau); Liceus (utilizados para o segundo grau); Ginásios (direcionados ao ensino de terceiro grau) e Academias (responsabilizadas pelo ensino superior). Em 1827, informa Santos (2015, p. 209), o Projeto foi aprovado, "com a inclusão e a obrigatoriedade, por parte das meninas, de aprendizagem de costura e bordado, sendo que nos Liceus os alunos aprenderiam o desenho, necessário às artes e aos ofícios".

Assim se constituíram, no século XIX, os Liceus de Artes e Ofícios: organizações de sociedades civis para amparar órfãos e ao mesmo tempo ofertar aprendizagem de artes e ofícios, formando mão de obra para atuar no mercado de trabalho do império. Eram dirigidos por nobres, fazendeiros, comerciantes e funcionários da burocracia estatal e se mantinham com recursos provenientes de quotas dos sócios e de doações, além de recursos do poder público devido à influência da burocracia do Estado nas direções dos Liceus. Os cursos eram gratuitos para filhos dos sócios ou qualquer indivíduo livre, sendo vedados apenas aos escravos; o que demonstra, segundo Santos (2015), que, apesar da nova estruturação do ensino, ainda permanecia a mesma discriminação contra a mão de obra escrava, praticada durante o período colonial. 
Cunha (2000, p. 92) sintetiza as iniciativas, no período do Império, voltadas para o ensino de ofícios. Segundo ele, Estado e sociedades civis pretendiam:

\begin{abstract}
a) imprimir a motivação para o trabalho; b) evitar o desenvolvimento de ideias contrárias à ordem política, de modo a não se repetirem no Brasil as agitações que ocorriam na Europa; c) propiciar a instalação de fábricas que se beneficiariam da existência de uma oferta de força de trabalho qualificada, motivada e ordeira; e d) favorecer os próprios trabalhadores, que passariam a receber salários mais elevados, na medida dos ganhos de qualificação.
\end{abstract}

Épossível observar que, na citação acima, não está inserida nenhuma restrição à abrangência do ensino de ofícios aos negros escravizados. Fala-se apenas em força de trabalho qualificada, motivada, ordeira. No entanto, os autores citados até aqui sobre o ensino profissional brasileiro no período colonial e imperial - Santos (2015) e Cunha (2000) - afirmam em seus trabaIhos que a discriminação para com os escravos era comum nos estabelecimentos de ensino de ofícios naquela época, normalmente sendo vedada a entrada deles nessas escolas. Logo, a qualificação para o trabalho era reservada ao trabalhador livre, muitas vezes miserável e, em especial, crianças e jovens também em situação de vulnerabilidade social.

Com a Proclamação da República, em 1889, caso houvesse alguma iniciativa por parte da União em promover a qualificação profissional também do negro liberto após a Abolição da Escravatura, em 1888, isto provavelmente deveria ter constado no Decreto 7566 de 23 de setembro de 1909 (BRASIL, 1909), que criava, nas capitais dos Estados brasileiros, as Escolas de Aprendizes e Artífices. O Decreto nada mencionou, no entanto, com relação ao aprendizado de profissões à mão de obra anteriormente escrava. Nas considerações iniciais do documento, observa-se a sua intencionalidade:

\title{
Considerando:
}

que o aumento constante da população das cidades exige que se facilite às classes proletárias os meios de vencer as dificuldades sempre crescentes da luta pela existência: que para isso se torna necessário, não só habilitar os filhos dos desfavorecidos da fortuna com o indispensável preparo técnico e intelectual, como fazê-los adquirir hábitos de trabalho profícuo, que os 
afastara da ociosidade ignorante, escola do vício e do crime;que é um dos primeiros deveres do Governo da República formar cidadãos úteis à Nação:

Decreta:

Art. $1^{\circ}$. Em cada uma das capitais dos Estados da República o Governo Federal manterá, por intermédio do Ministério da Agricultura, Indústria e Comércio, uma Escola de Aprendizes Artífices, destinada ao ensino profissional primário gratuito (BRASIL, 1909, p. 01).

O público alvo do ensino profissional primário gratuito está especificado no Art. $6^{\circ}$ do Decreto (BRASIL, 1909) onde há os requisitos para matrícula, salientando-se que os preferidos eram os "desfavorecidos da fortuna": um requisito era idade de 10 anos no mínimo e de 13 anos no máximo; outro era não sofrer o candidato de moléstia infectocontagiosa, nem ter defeitos que o impossibilitassem para o aprendizado do ofício. O Art. $8^{\circ}$ indicava que os cursos eram noturnos: o primário, obrigatório para os alunos que não soubessem ler, escrever e contar; e outro de desenho, também obrigatório, para os alunos que precisassem dessa disciplina para o exercício do ofício.

A criação das 19 unidades das Escolas de Aprendizes e Artífices pelo então Presidente da República, Nilo Peçanha, em 1909, é considerada o início do ensino profissional no Brasil. O Ministério da Educação, por ocasião da celebração ao centenário da educação profissional e tecnológica brasileira, em 2009, publicou o Histórico da Educação Profissional (BRASIL, [2007?], p.02) que assinala a criação da Rede Federal de Educação Profissional e Tecnológica a partir da assinatura, por Nilo Peçanha, em 23 de setembro de 1909, do Decreto no 7.566, "criando, inicialmente em diferentes unidades federativas, sob a jurisdição do Ministério dos Negócios da Agricultura, Indústria e Comércio, dezenove 'Escolas de Aprendizes Artífices', destinadas ao ensino profissional, primário e gratuito".

As Escolas de Aprendizes e Artífices, no entanto, demonstraram, segundo Santos (2015), baixa eficiência: edifícios inadequados, oficinas precárias, escassez de mestres de ofícios especializados e de professores qualificados. Além disso, altos índices de evasão: poucos alunos chegavam ao final dos cursos, pois precisavam empregar-se nas fábricas com os conhecimentos mínimos que conseguiam até a $3^{\text {a }}$ série dos mesmos.

Penso, em seguida, em como esse dualismo se apresenta na educação brasileira no presente, considerando a concepção conserva- 
dora e discriminatória que acompanhou o ensino de profissões nos primeiros anos de sua existência no Brasil.

\section{Neoliberalismo, crise, reformas educacionais e o dualismo atual}

Em 2008, a Lei 11.892 (BRASIL, 2008) institui a Rede Federal de Educação Profissional, Científica e Tecnológica, cria os Institutos Federais de Educação, Ciência e Tecnologia e consolida o chamado período de expansão da Rede Federal de Educação Profissional, Científica e Tecnológica. O caráter assistencialista e dualista que historicamente acompanhou a educação profissional deveria ser substituído por um novo projeto, cujo foco se desloca para a qualidade social.

Uma situação de crise, porém, atinge todas as esferas do poder público a partir de 2015. Confirmam essa situação de crise as notícias dos jornais do período. Em 01 de janeiro de 2016, o jornal O Estado de São Paulo (SALDAÑA, 2016) publicava uma notícia com a seguinte manchete: "No ano do lema 'Pátria Educadora', MEC perde R\$10,5 bi, ou $10 \%$ do orçamento". O jornal informava ainda que, antes mesmo de oficializar o represamento de orçamento no âmbito do ajuste fiscal, os cortes atingiram programas como o Financiamento Estudantil (FIES) e o Programa Nacional de Acesso ao Ensino Técnico e Emprego - (PRONATEC). (SALDAÑA, 2016).

As Universidades Federais e os Institutos Federais, segundo o jornal O Dia (CARDOSO, 2016), vivem grave crise financeira com redução de programas, contratos e até dificuldades para pagar contas. Segundo cálculos de gestores, seriam cerca de $\mathrm{R} \$ 350$ milhões a menos em investimentos para as 63 federais - na comparação com os $R \$ 900$ milhões previstos para o setor em 2016.

Uma característica especial das crises contemporâneas, conforme Bauman e Bordoni (2016), é a sua duração. Parece que nunca vai acabar. As crises, vagas e generalizadas progridem muito lentamente, em contraste com a velocidade das demais atividades humanas. Quando uma crise acaba, outra entra em cena e toma seu lugar. Nós temos de nos habituar a conviver com a crise, pois a crise está aqui para ficar. (BAUMAN; BORDONI, 2016, p. 15).

O fato de as crises produzidas na sociedade contemporânea aparentemente serem infinitas remete à produção das mesmas pelo neoliberalismo. $\mathrm{O}$ que chamamos de neoliberalismo é uma arte de governo, 
segundo Foucault (2008). A capacidade de nos autogovernarmos mais e melhor está imbricada, conforme o autor, em um importante conceito, o de governamentalidade. Foucault $(2016$, p. 429) explica que, com essa palavra, quer dizer:

[...] o conjunto constituído pelas instituições, procedimentos, análises e reflexões, cálculos e táticas que permitem exercer esta forma bastante específica e complexa de poder, que tem por alvo a população, por forma principal de saber a economia política e por instrumentos técnicos essenciais os dispositivos de segurança. [...].

O que Foucault vai chamar de táticas, tecnologias, "mecanismos ou dispositivos de segurança", são racionalidades que exercem o poder não diretamente nos sujeitos, mas mediante intervenções mais ou menos pontuais no meio em que os sujeitos vivem. É produzida, no caso do neoliberalismo, uma sociedade espelhada no modelo-empresa, cuja lógica está pautada no investimento perene no capital humano, na competitividade, na liberdade e na (hiper)responsabilização individual.

Podemos perceber a importância da educação nesse processo. $\mathrm{Na}$ contemporaneidade, os meios pelos quais os sujeitos acessam a educação transcenderam em larga escala a educação escolar, mas não prescindiram dela efetivamente. Não há, nessa lógica, uma formação educacional acabada, não há formação definitiva. Ideias como educação permanente, indivíduo aprendiz, formação continuada, empreendedorismo, entre outras, constituem o nexo que relaciona os sujeitos ao neoliberalismo.

Silva (SANTOS, 2017) afirma que as políticas implementadas neste contexto tomam a própria noção de "crise" como operador estratégico para sua racionalidade. Emerge um novo modo de governabilidade que consiste em usar a crise como ponto crucial para acelerar o estabelecimento da lógica de mercado e as regras de concorrência no âmago do emprego e da sociedade. A intensificação na gramática da crise política, de forma ambivalente, segundo Silva (SANTOS, 2017), justifica a mobilização de reformas permanentes. Neste cenário, então, podemos encontrar os atuais movimentos de reforma engendrados pelo Estado brasileiro, dentre essas reformas, cabe destaque, por sua relação com a educação profissional, a reforma do Ensino Médio ${ }^{4}$.

4 A reforma do Ensino Médio, Lei n. 13.415, de 16 de fevereiro de 2017 (BRASIL, 2017), dentre 
Tal reforma investe em um Ensino Médio que permita percursos formativos aliados a uma formação técnica ou profissional e que possa fazer emergir um jovem forjado no empreendedorismo. Num universo escolar institucionalmente unificado, mas socialmente diversificado, onde cada indivíduo torna-se responsável por seu próprio destino escolar, a tendência à individualização dos percursos se acentua. Esse processo pode converter os estudantes em estrategistas de seus percursos; porém, partindo de recursos desiguais. Este cenário, segundo Silva (SANTOS, 2017), pode reforçar o histórico dualismo das políticas educacionais brasileiras, intensificado com a emergência de novas precariedades. A partir dessa análise de Silva (SANTOS, 2017) é pertinente pensar que o caráter dualista da educação profissional ainda se mantém em nosso país, agora atendendo às estratégias meritocráticas de ascensão social da governamentalidade neoliberal.

\section{Considerações finais}

Diante dessa discussão, que reflexão se coloca? O que se concentra, neste momento de crise, é o questionamento a respeito desse processo: essa dualidade está totalmente "resolvida"? Como se observa nas discussões deste texto, a educação profissional se constrói, no Brasil, com um caráter assistencialista e dualista em meio a uma ética da desvalorização do trabalho, uma vez que trabalhar era uma atribuição para os escravos. Como o trabalho foi culturalmente construído como um castigo, um sofrimento, o ensino das profissões manuais ou que exigem esforço físico (trabalho desvalorizado socialmente) também foi se separando do ensino regular que preparava os jovens para acessar a universidade, onde se aprende o trabalho valorizado socialmente.

Atualmente, o discurso do ensino técnico ainda está ligado à formação dos menos favorecidos, dos trabalhadores do mercado, ou seja, à

outras mudanças, prevê a segmentação de disciplinas com uma parte obrigatória e outra optativa, o aumento da carga horária e a implantação do ensino integral. Haverá uma base curricular comum a todas as escolas (60\% das disciplinas) e uma parte flexível (40\%), que poderá ser adaptada à realidade de cada região. O currículo será definido a partir da Base Nacional Comum Curricular (BNCC) e de "itinerários formativos" correspondentes a cinco áreas do conhecimento: Linguagem e suas tecnologias; Matemática e suas tecnologias; Ciências da natureza e suas tecnologias; Ciências humanas e sociais aplicadas; e Formação técnica e profissional. As escolas não serão obrigadas a oferecer todas as cinco áreas, mas terão de ofertar ao menos uma delas. A reforma aumenta a carga horária do Ensino Médio das atuais 800 horas anuais ( 4 horas por dia) para no mínimo 1.000 ( 5 horas por dia) até 2022. 
preparação da mão de obra necessária ao desenvolvimento econômico e social do país - o que é positivo, necessário e louvável que ocorra - porém, desta forma também legitima um discurso neoliberal que pretende manter uma educação para os "pobres" e outra para os "ricos".

Viver em estado de crise não é agradável, mas pode ter seu lado positivo, pois mantém os sentidos vigilantes e alertas. Bauman e Bordoni (2016) defendem que a crise na contemporaneidade transmite uma imagem de momento de transição de uma condição anterior para uma nova - de uma transição que se presta necessariamente ao crescimento como prelúdio de uma melhoria para um status diferente, um passo adiante decisivo. Nesse sentido, pensar a educação profissional brasileira neste momento de crise, mas levando em consideração sua gênese assistencialista e o dualismo que com ela se instala na educação nacional, é importante para que a ansiedade do sentimento de incerteza que este processo agrega se transforme em fortalecimento das faculdades críticas e autocríticas e em coragem necessária para assumir a responsabilidade de enfrentar possíveis mudanças.

\section{Referências}

BAUMAN, Z.t; BORDONI, C. Estado de crise. Rio de Janeiro: Zahar, 2016. BRASIL. Decreto no 7566, de 23 de setembro de 1909. Crêa nas capitaes dos Estados da Republica Escolas de Aprendizes Artifices, para o ensino profissional primario e gratuito. Diário Oficial da União: Rio de Janeiro, RJ, p. 6975, 26 set. 1909. Disponível em: https://www2.camara.leg.br/ legin/fed/decret/1900-1909/decreto-7566-23-setembro-1909-525411publicacaooriginal-1-pe.html. Acesso em: 23 Fev. 2019.

BRASIL. Congresso Nacional. Lei no 11.892, de 29 de dezembro de 2008. Institui a Rede Federal de Educação Profissional, Científica e Tecnológica, cria os Institutos Federais de Educação, Ciência e Tecnologia, e dá outras providências. Diário Oficial da União: Brasília, DF, 30 dez. 2008. Disponível em: www.planalto.gov.br/ccivil_03/_ato2007.../2008/lei/ 111892.htm. 2008. Acesso em: 10 Set. 2018.

BRASIL. Congresso Nacional. Lei n. 13.415, de 16 de fevereiro de 2017. Altera as Leis n ${ }^{\circ}$ 9.394, de 20 de dezembro de 1996, que estabelece as diretrizes e bases da educação nacional, e 11.494, de 20 de junho 2007, que regulamenta o Fundo de Manutenção e Desenvolvimento 
da Educação Básica e de Valorização dos Profissionais da Educação, a Consolidação das Leis do Trabalho - CLT, aprovada pelo Decreto-Lei ${ }^{\circ}$ 5.452 , de $1^{\circ}$ de maio de 1943 , e o Decreto-Lei no 236 , de 28 de fevereiro de 1967; revoga a Lei no 11.161, de 5 de agosto de 2005; e institui a Política de Fomento à Implementação de Escolas de Ensino Médio em Tempo Integral. Diário Oficial da União: Brasília, DF, 17 fev. 2008. Disponível em: http://www.planalto.gov.br/ccivil_03/_ato2015-2018/2017/lei/ 113415.htm. 2017. Acesso em: 24 mar. 2018.

CANDIDO, A. O significado de "Raízes do Brasil". In: HOLANDA, S. B.. Raízes do Brasil. 26. ed. São Paulo: Companhia das Letras, 1995. p. 0921.

CUNHA, L. A. O ensino industrial-manufatureiro no Brasil. Revista Brasileira de Educação, n. 14, p. 89-107, maio/ago, 2000.

FONSECA, C. S. História do Ensino Industrial no Brasil. Rio de janeiro: Escola Técnica, 1961.

FOUCAULT, M. Nascimento da biopolítica: Curso dado no College de France (1978-1979). São Paulo: Martins Fontes, 2008.

FOUCAULT, M. Microfísica do poder. 4.ed. Rio de Janeiro: Paz e Terra, 2016.

HOLANDA, S. B. Raízes do Brasil. 26. ed. São Paulo: Companhia das Letras, 1995.

BRASIL. Ministério da Educação. Histórico da educação profissional no Brasil. [2007?]. Disponível em: http://portal.mec.gov.br/setec/arquivos/ centenario/historico_educacao_profissional.pdf. Acesso em: 24 nov. 2017.

CARDOSO, L.. Universidades federais deverão ter corte de até $45 \%$ nos investimentos. O Dia, 11 ago. 2016. Disponível em: https://odia.ig.com. br/_conteudo/educacao/2016-08-11/universidades-federais-deveraoter-corte-de-ate-45-nos-investimentos.html. Acesso em: 10 set. 2018.

SALDAÑA, P.. No ano do lema 'Pátria Educadora', MEC perde R\$10,5 bi, ou $10 \%$ do orçamento. O Estado de São Paulo, 1 jan. 2016. Disponível em: http://educacao.estadao.com.br/noticias/geral,no-ano-do-lemapatria-educadora--mec-perde-r-10-5-bi--ou-10-do-orcamento, 1817192. Acesso em: 10 set. 2018.

SANTOS, J. A.. A trajetória da educação profissional. In: LOPES, E. M. T.; 
FARIA FILHO, L. M.; VEIGA, C. G. (Orgs). 500 anos de educação no Brasil. 5.ed. Belo Horizonte: Autêntica, 2015. p. 205 - 224.

SCHWARCZ, L. M.; STARLING, H. M. Brasil: uma biografia. São Paulo: Companhia das Letras, 2015.

SANTOS. J. V. No discurso de crises, a busca por uma educação utilitarista e neoliberal. Entrevistado: Roberto Dias da Silva. IHU On-Line, São Leopoldo/RS, 22 maio 2017. Disponível em: http://www.ihuonline. unisinos.br/artigo/6884-no-discurso-de-crises-a-busca-por-umaeducacao-utilitarista-e-neoliberal. Acesso em: 10 Set. 2018.

VEIGA-NETO, A. Foucault \& a educação. 3.ed. Belo Horizonte: Autêntica, 2011.

WEBER, M. A ética protestante e o "espírito" do capitalismo. São Paulo: Companhia das Letras, 2004.

Recebido em: Julho/2019

Aceito em: Março/2020 